\title{
Trace element accumulation and distribution in sunflower plants at the stages of flower bud and maturity
}

\author{
Susanna De Maria, Anna Rita Rivelli \\ School of Agricultural, Forest, Food and Environmental Sciences, University of Basilicata, \\ Potenza, Italy
}

\begin{abstract}
The aim of this study was to analyze the accumulation and distribution of cadmium (Cd), zinc ( $\mathrm{Zn}$ ) and copper ( $\mathrm{Cu})$ in different portions of plants of sunflower (Helianthus annuus $\mathrm{L}, \mathrm{cv}$. Oleko) grown in soil with contaminants (5, 300, $400 \mathrm{mg} \mathrm{kg}^{-1}$ of $\mathrm{Cd}, \mathrm{Zn}$ and $\mathrm{Cu}$, respectively) and without (untreated soil as a control) from the emergence of cotyledon leaves until to two phenological stages: flower bud (R-1) and maturity (R9). Sunflower accumulated considerable amounts of heavy metals in both phenological stages showing slight reductions of dry matter production. At R-1 stage, $\mathrm{Cd}, \mathrm{Zn}$ and $\mathrm{Cu}$ were accumulated mainly in the roots with concentrations respectively up to $5.4,233$ and $160 \mathrm{mg} \mathrm{kg}^{-1}$ of dry matter with a low translocation from roots to the aerial part. Yet at the R-1 stage, the bioconcentration factor (BCF) of Cd showed a significantly higher value in the $\mathrm{Cd}-\mathrm{Zn}$-Cu treatment $(0.27)$ with respect to the untreated control (0.02), vice versa was observed for $\mathrm{Cu}$, whereas no significant difference between treatments was observed for $\mathrm{Zn} \mathrm{(0.12} \mathrm{on} \mathrm{average).}$ However among metals, Cd showed the highest value of BCF. Referring only to the epigeous portion, differences in the accumulation and distribution of the three metals in the treated plants were found in both phenological stages; indeed passing from flower bud to the maturity stage, $\mathrm{Cd}, \mathrm{Zn}$ and $\mathrm{Cu}$ concentrations increased in the stems and leaves, particularly in the old ones, whereas decreased in the heads. Metal accumulation in the achenes was very low and never exceed the toxicity threshold value considered for livestock. The high storage of heavy metals in roots
\end{abstract}

Correspondence: Anna Rita Rivelli, Scuola di Scienze Agrarie, Forestali, Alimentari e dell'Ambiente, Università della Basilicata, via dell'Ateneo Lucano 10, 85100 Potenza, Italy.

Tel. +39.0971.205382 - Fax: +39.0971.205378.

E-mail: annarita.rivelli@unibas.it

Key words: cadmium, copper, Helianthus annuus L., phenological stage, phytoremediation, zinc.

Conference presentation: SIA Congress, Bari 2012.

Received for publication: 31 October 2012.

Revision received: 12 February 2013.

Accepted for publication: 15 February 2013.

(C) Copyright S. De Maria and A.R. Rivelli, 2013

Licensee PAGEPress, Italy

Italian Journal of Agronomy 2013; 8:e9

doi:10.4081/ija.2013.e9

This article is distributed under the terms of the Creative Commons Attribution Noncommercial License (by-nc 3.0) which permits any noncommercial use, distribution, and reproduction in any medium, provided the original author(s) and source are credited. and the probable re-translocation of the three metals along the plant during the growing cycle could be considered as a strategy of sunflower to preserve young metabolically-active leaves and reproductive organs from toxic metal concentrations.

\section{Introduction}

Soil contamination is a global environmental issue of increasing interest and concern considering the risk that contaminants can enter the ground and surface water and the food human chain. Recently, the European Environment Agency (EEA, 2007) estimated that in Europe there are about 3 millions sites in which potentially polluting activities occurring, and at least 250,000 really polluted sites (including agricultural lands) requiring an urgent clean up.

Several remediation technologies, mechanically or physico-chemically based, have been developed to remove contaminants from soil; nevertheless, most of them resulted usually expensive and soil disturbing, sometimes rendering the land useless as a medium for further activities such as plant growth (Marques et al., 2009). Therefore, the idea to use the plants to remove, detoxify and/or stabilize contaminants from the soil, i.e. the phytoremediation technologies, introduced 30 years ago from Chaney (1983), rapidly gained the interest of numerous scientists and an extensive literature was produced on plant species suitable for phytoremediation, from the wild to the cultivated species (Cunningham and 0w, 1996; Baker et al., 2000; Lasat, 2000; Prasad and Freitas, 2003; Ghosh and Singh, 2005). Meantime, the plant-based remediation technologies were recognized as effective and inexpensive technologies, low invasive and environmentally sound, aesthetically and socially acceptable and generally in harmony with the landscape (Garbisu et al., 2002; Ghosh and Singh, 2005). Besides, Marchiol and Fellet (2011) recently highlighted the fundamental role of the agronomic approach in the management of phytoremediation programs and the agronomic practices whose effects on plant/soil/contaminant interaction would optimize the phytoremediation processes to site specific conditions. The same authors underlined that such phytotechnologies should be promoted especially in view of the scenario of the Green Economy. However, the research is currently directed towards the selection of woody plants and agricultural crops able to tolerate and accumulate contaminants gradually remediating the soil at low cost while producing harvestable biomass of economic interest usable for specific purposes (e.g. bioenergy) and generating value added (Meers et al., 2005; Tognetti et al., 2013). Accordingly, sunflower (Helianthus annuus L.), an increasingly important source of vegetable oil and biomass, usefully employed for chemical, energy and industrial purposes (Riva and Calzoni, 2004), gained growing interest in the last years for phytoremediation of organic compounds and heavy metals (Prasad, 2007). This latter group of pollutants, named also trace elements, includes metals with any essential biological function (e.g., mercury, lead and cadmium), and metals that 
are essential for plants but can become toxic at high concentrations [e.g., zinc $(\mathrm{Zn})$, copper $(\mathrm{Cu})$ and iron $(\mathrm{Fe})]$. Although all metals are natural constituents of the earth's crust at levels that are regarded as trace $\left(<1000 \mathrm{mg} \mathrm{kg}^{-1}\right)$ and rarely toxic, the indiscriminate human activities have drastically altered their geochemical cycles and biochemical balance (Singh et al., 2011). In addition, conversely to the organic pollutants, heavy metals cannot be destroyed biologically but only transformed from one oxidation stage or organic complex to another (Garbisu and Alkorta, 2001), resulting almost indefinitely persistent into the environment.

In field, pot and hydroponic trials, under different contaminated conditions, the capacity of sunflower to accumulate heavy metals has been evaluated. It has been reported that sunflower accumulates large amounts of several metals [e.g., Zn, lead (Pb), Cu] in plant (Lin et al., 2003; Madejón et al., 2003; Marchiol et al., 2007; Adesodun et al., 2010; Vamerali et al., 2012). Nevertheless, contrasting are the reports about metals translocation and storage in plant; according to many authors, it tends to store and accumulate such metals mainly in roots, with low efficiency in the translocation from the roots to the shoots (Lin et al., 2003; Madejón et al., 2003; Marchiol et al., 2007), whereas other authors report that sunflower efficiently translocates several metals to its aerial part (Herrero et al., 2003; Adesodun et al., 2010). However accumulation of metals and their distribution in plants, as well as their effect on plant growth response, seem vary greatly among cultivars, portions of the plant, phenological stage, degree of contamination and combination of metals (Madejòn et al., 2003; Nehnevajova et al., 2005; Rivelli et al., 2012). Results of our previous research on plants of sunflower grown in soil with only cadmium $(\mathrm{Cd})$ and with a combination of $\mathrm{Cd}$ plus $\mathrm{Zn}$ and $\mathrm{Cu}$, showed that only the pluri-contaminated treatment involved a significative effect on plant growth and physiological response with a considerable accumulation of metals in the tissues, particularly in the roots and in the old leaves (Rivelli et al., 2012). Following those results and using the same specie and genotype, the purpose of the present study was to assess the capacity of sunflower to remove the contaminants $(\mathrm{Cd}, \mathrm{Zn}$ and $\mathrm{Cu}$ ) from the soil by analyzing the translocation and storage of metals in plant tissues and their effect on growth in two phenological phases: flower bud and maturity.

\section{Materials and methods}

\section{Experimental protocols and treatments}

The experiment was carried out in 2009 at the University of Basilicata, Italy $\left(40^{\circ} 36^{\prime} \mathrm{N}, 15^{\circ} 48^{\prime} \mathrm{E}\right)$ in a naturally lit and temperatecontrolled glasshouse maintained at $26^{\circ} \mathrm{C}$ during the day and $18^{\circ} \mathrm{C}$ at night. Sunflower (Helianthus annuus $\mathrm{L}$, cv. Oleko) plants were grown in untreated soil as a control (untreated) and in soil contaminated with $5,300,400 \mathrm{mg} \mathrm{kg}^{-1}$ of $\mathrm{Cd}, \mathrm{Zn}$ and $\mathrm{Cu}$, respectively (Cd-Zn-Cu), from the emergence of cotyledon leaves until to the two different phenological stages: flower bud (R-1) and maturity (R-9). The phenological stages were classified according to Schneiter and Miller (1981) and identified by using the same codes of the authors (R-1 and R-9, respectively).

The experimental soil was a clay loam; it was collected from the top $20 \mathrm{~cm}$ layer of an arable soil near Potenza (Italy), air-dried and homogenized before use. Detailed information on the soil and its physical and chemical characteristics are shown in Table 1 . Sixteen pots $(20 \emptyset \times 80$ $\mathrm{cm}$ each) were filled with $10 \mathrm{~kg}$ of soil, sealed at the base to prevent loss of water and soil, and randomly divided into two groups: the untreated control and the contaminated treatment to which a solution of contaminants was applied. Contaminants were added as cadmium sulphate $\left(\mathrm{CdSO}_{4}\right)$, zinc sulphate $\left(\mathrm{ZnSO}_{4}\right)$ and copper sulphate $\left(\mathrm{CuSO}_{4}\right)$. Soil con- tamination was accomplished by bringing the soil to maximum water holding capacity with aqueous solutions containing $86.5 \mathrm{mg}$ of $\mathrm{CdSO}_{4}$, $12.27 \mathrm{~g}$ of $\mathrm{ZnSO}_{4}$ and $14.62 \mathrm{~g}$ of $\mathrm{CuSO}_{4}$ to provide a contamination level of 5, 300 and $400 \mathrm{mg}$ of $\mathrm{Cd}, \mathrm{Zn}$ and $\mathrm{Cu} \mathrm{kg}^{-1}$ of soil, respectively. After four weeks, seeds, preliminarily selected by weight (150-200 mg) and surface sterilized with $1 \%$ sodium hypochlorite, were pre-germinated in Petri dishes for 3 days and then planted one per each pot. The seedlings in each pot were monitored from the emergence of cotyledon leaves until to the two different phenological stages (R-1 and R-9) when plants were harvested. The experimental design was a completely randomized design with two treatments (untreated and $\mathrm{Cd}-\mathrm{Zn}-\mathrm{Cu}$ ) replicated four times for each phenological stage.

\section{Data collection and analysis}

Dry matter and tissue trace element concentrations were determined at both phenological stages (R-1 and R-9) for all portions of the plants, except for roots at the physiological maturity (R-9) (since the plants, including roots, were dry and it was difficult to separate roots from soil and to collect all of them from the pots). Plants were harvested by cutting the stem at soil level and immediately partitioned into head, stem and leaves [divided into young, mature and old ones (i.e. at the top, middle and basal portion of the stem)]. Roots were quickly separated from the adhering soil by washing and then sonicated in $0.05 \mathrm{M} \mathrm{CaCl}_{2}$ for $10 \mathrm{~min}$ in an ultrasonic bath (Transsonic T 460/H, Elma, Germany) and rinsed with deionised water to remove extra metals from the apparent free space of the root tissues. All samples were dried in ventilated oven at $70^{\circ} \mathrm{C}$ for $48 \mathrm{~h}$, weighted to determine the dry matter weight (DM) and ground in a stainless box mill. Subsamples of $0.5 \mathrm{~g}$ were digested in a high performance microwave digestion unit (Milestone 1200 MEGA, Monroe, CT, USA) by using 5 mL $\mathrm{HNO}_{3}$ (Puriss. p.a.;

Table 1. Experimental soil properties.

\begin{tabular}{lcc} 
Characteristics & Units & Value \\
Sand & $\mathrm{g} \mathrm{kg}^{-1}$ & 361 \\
Silt & $\mathrm{g} \mathrm{kg}^{-1}$ & 286 \\
\hline Clay & $\mathrm{g} \mathrm{kg}^{-1}$ & 353 \\
$\mathrm{CEC}$ & $\mathrm{cmol} \mathrm{kg}^{-1}$ & 36 \\
\hline $\mathrm{pH}\left(\mathrm{CaCl}_{2}\right)$ & - & 7.1 \\
$\mathrm{EC}$ & $\mathrm{ms} \mathrm{cm}^{-1}$ & 0.14 \\
\hline Organic matter & $\mathrm{g} \mathrm{kg}^{-1}$ & 20 \\
Total nitrogen & $\mathrm{g} \mathrm{kg}^{-1}$ & 1.2 \\
\hline & Exchangeable cations & \\
\hline Potassium & $\mathrm{mg} \mathrm{kg}^{-1}$ & 281 \\
Calcium & $\mathrm{mg} \mathrm{kg}^{-1}$ & 6670 \\
\hline Magnesium & $\mathrm{mg} \mathrm{kg}^{-1}$ & 219 \\
& Extractable cations \\
\hline Cadmium & $\mathrm{mg} \mathrm{kg}^{-1}$ & 0.006 \\
Zinc & $\mathrm{mg} \mathrm{kg}^{-1}$ & 0.9 \\
\hline Copper & $\mathrm{mg} \mathrm{kg}^{-1}$ & 3.7 \\
\hline Cadmium & Total metal concentration \\
\hline Copper & $\mathrm{mg} \mathrm{kg}^{-1}$ & 0.27 \\
\hline & $\mathrm{mg} \mathrm{kg}^{-1}$ & 180 \\
\hline & $\mathrm{mg} \mathrm{kg}^{-1}$ & 62 \\
\hline
\end{tabular}

CEC, cation exchange capacity; EC, electrical conductivity. 
Sigma-Aldrich, St. Louis, MO, USA) and $1 \mathrm{~mL} \mathrm{H}_{2} \mathrm{O}_{2}$ (Puriss.; Carlo Erba, Milano, Italy). The digestion time period was $32 \mathrm{~min}$ after then $50 \mathrm{~mL}$ of distilled water were added to the sample volume. The resulting solutions were analyzed for $\mathrm{Cd}, \mathrm{Zn}$ and $\mathrm{Cu}$ by using an Inductively Coupled Plasma, Optical Emission Spectrometer (ICP-OES Spectrometer, iCAP 6000 Series, Thermo Scientific, Waltham, MA, USA).

Soil samples, before and after the contamination, were taken and processed to determinate the $\mathrm{Cd}, \mathrm{Zn}$ and $\mathrm{Cu}$ concentrations. For each sample, a subset of $0.5 \mathrm{~g}$ of soil was digested with aqua regia and $\mathrm{H}_{2} \mathrm{O}_{2}$, as described by Leita and Petruzzelli (2000) by using a high performance microwave digestion unit (Milestone 1200 MEGA). The digestion time period was $45 \mathrm{~min}$ after then $50 \mathrm{~mL}$ of distilled water were added to the sample volume. Then soil trace element concentrations were determined by an Inductively Coupled Plasma, Optical Emission Spectrometer (ICP-OES Spectrometer, iCAP 6000 Series, Thermo Scientific). Certified reference material was always digested and analyzed together with the sample for quality assurance.

The bioconcentration factor (BCF) was calculated as metal concentration in the tissues (considering the whole plant at R-1 stage, the aerial part or only the old leaves at both R-1 and R-9 stages) divided by the total metal concentration in the soil (measured after contamination immediately before to plant the germinated seeds). The translocation factor (TF) was calculated at R-1 stage as metal concentration in the aerial part divided by the concentration in the roots.

\section{Statistical analysis}

All data are presented as average values \pm SE. Statistical analysis was performed by $\mathrm{R}$ software (ver. 2.10.1). All variables were tested with multifactor analysis of variance followed by Duncan's test. A Student test was used to assess differences in concentrations of trace elements in the achenes between the contaminated treatment and the untreated control.

\section{Results}

The total plant DM was of about 64 and $60 \mathrm{~g}$ per plant in the control and 53 and $44 \mathrm{~g}$ per plant in the treated plants, at the flower bud (R-1) and maturity stages (R-9), respectively (data not shown). The dry matter relative to the different portions of the plants at the R-1 and R-9 stages has been reported in Figure 1 and showed as percentage of dry matter reduction of the $\mathrm{Cd}-\mathrm{Zn}-\mathrm{Cu}$ treatment with respect to the untreated control. An overall reduction of DM in almost all portions of the plants grown on contaminated soil was observed at both the phenological stages. In particular, significant reduction of about $25 \%$ was found in the stem DM at the R-1 stage; whereas the heads significantly increased by $10 \%$ in the R- 1 stage and decreased by $37 \%$ at R- 9 stage. At the $\mathrm{R}-1$ stage, $\mathrm{Cd}, \mathrm{Zn}$ and $\mathrm{Cu}$ concentrations were evaluated in both roots and aerial part (Figure 2); regardless of treatments, all metals were accumulated mainly in the roots; in particular, in pluri-contaminated treatment, $\mathrm{Cd}, \mathrm{Zn}$ and $\mathrm{Cu}$ concentrations were respectively 9-3and 13- fold higher in the roots compared to the aerial part. At this stage, the total amount of contaminants extracted by sunflower and accumulated in the whole plant were about of $1.3,92.5$ and $35.4 \mathrm{mg} \mathrm{kg}^{-1}$ $\mathrm{DM}$ of $\mathrm{Cd}, \mathrm{Zn}$ and $\mathrm{Cu}$, respectively (data not shown). Considering the bioconcentration factor (BCF) (Figure 3A) Cd showed a significantly higher value in the contaminated treatment $(0.27)$ with respect to the untreated control (0.02), vice versa was observed for $\mathrm{Cu}$, whereas no significant difference between treatments was observed for $\mathrm{Zn}$ ( 0.12 on average). However, among metals, Cd showed the highest value of BCF. Referring to TF (Figure 3B), except for $\mathrm{Cu}$, no significant difference

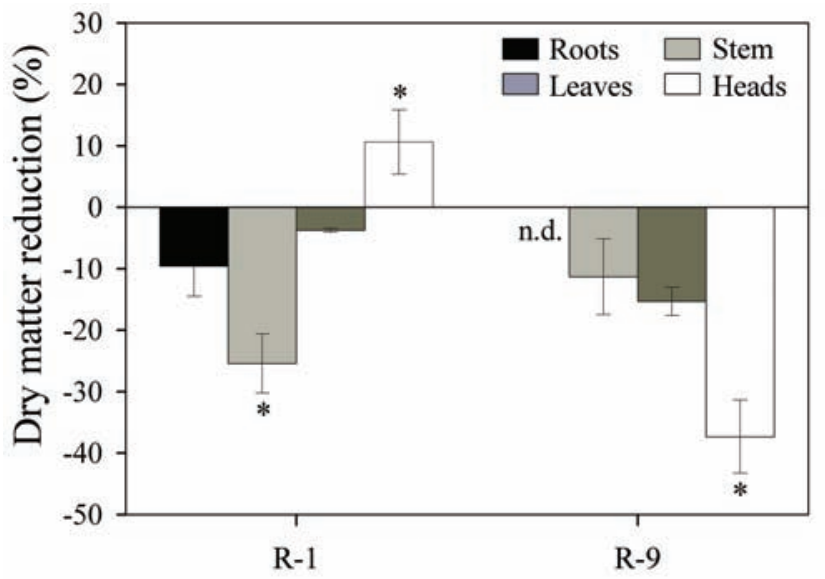

Figure 1. Dry matter reduction (\% of the untreated treatment) of sunflower plants grown on contaminated soil at flower bud (R-1) and maturity $(\mathrm{R}-9)$ stages. Values are means $(\mathrm{n}=4) \pm \mathrm{SE}$. Values differing significantly from the control $(P \leq \mathbf{0 . 0 5})$ are labelled with an asterisk.

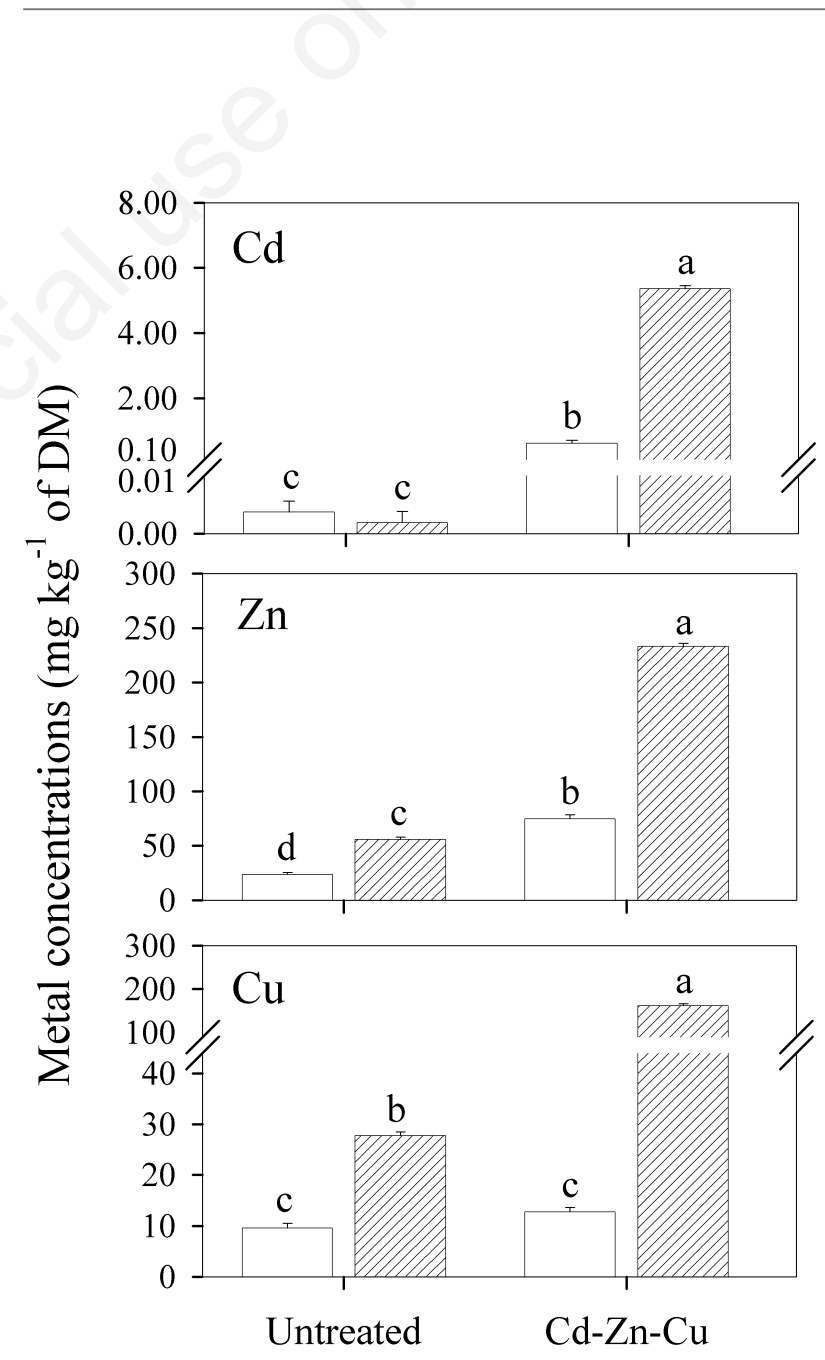

Figure 2. Metal concentrations in the aerial part (white bars) and roots (pattern bars) of sunflower at the flower bud stage. Values are means $(n=4) \pm S E$. For each metal, bars followed by the same letters are not significantly different for $\mathrm{P} \leq \mathbf{0 . 0 5}$ according to Duncan's test. DM, dry matter. Cd, cadmium; $\mathrm{Zn}$, zinc; $\mathrm{Cu}$, copper. 
was observed between treatments for $\mathrm{Cd}$ (0.12 on average) and $\mathrm{Zn}$ ( 0.36 on average). Among metals, $\mathrm{Zn}$ (in both treatments) and $\mathrm{Cu}$ (only in untreated control) showed the highest TF values that were not significantly different from each other. Considering only the contaminated treatment $\mathrm{Cu}$ showed the lowest value of TF.

In Figure 4 has been reported, for both the phenological stages, the heavy metal concentration and distribution in the different portions of the aerial part. Generally, all metals increased passing from the R-1 stage to the R-9 stage in both stem and leaves; conversely was observed in the heads. In particular, $\mathrm{Cd}$ concentration in the contaminated treatment increased of $50 \%$ and $340 \%$ in the stem and leaves respectively, whereas it decreased of about $25 \%$ in the heads; no differences were observed between portions and phenological stages in the untreated control. As for cadmium, $\mathrm{Zn}$ and $\mathrm{Cu}$ in the contaminated treatment increased respectively of about $70 \%$ and $125 \%$ in stems, and $240 \%$ and $790 \%$ respectively in leaves, and decreased of $40 \%$ on average in head; instead, in the untreated control, no differences in $\mathrm{Zn}$ and $\mathrm{Cu}$ concentrations in each portion were observed between the two phenological stages, except for $\mathrm{Zn}$ in stem (+106\%) and $\mathrm{Cu}$ in leaves and in heads (+38\% and $-43 \%$, respectively). However, leaves showed at R-9 stage the highest values of concentration for $\mathrm{Cd}, \mathrm{Zn}$ and $\mathrm{Cu}$. The total amounts of contaminants extracted by sunflower and accumulated only in the harvestable biomass were respectively of $0.62,74.6$ and $12.7 \mathrm{mg}$ $\mathrm{kg}^{-1}$ D.M. of Cd, $\mathrm{Zn}$ and $\mathrm{Cu}$ at R-1 and 0.88, 123 and $46.9 \mathrm{mg} \mathrm{kg}^{-1}$ D.M. of $\mathrm{Cd}, \mathrm{Zn}$ and $\mathrm{Cu}$ respectively, at R-9 (data not shown).

Referring to the concentration of each metal in the leaves, divided in young, mature and old ones respectively at the top, middle and basal portion of the stem (Table 2), a significant interaction $(\mathrm{P} \leq 0.001)$ was found among treatment, leaf age and phenological stage. In particular in each phenological stage an overall increase of metal concentrations was observed passing from the young to the old leaves in the treated plants, with significantly highest values in the old ones at the maturity stage $\left(6.4,497\right.$ and $474 \mathrm{mg} \mathrm{kg}^{-1} \mathrm{DM}$ of $\mathrm{Cd}, \mathrm{Zn}$ and $\mathrm{Cu}$, respectively). Instead, passing from R-1 to R-9 stage in the young leaves the concentrations of Cd and Zn significantly decreased from 0.71 to $0.13 \mathrm{mg} \mathrm{kg}^{-1}$ $\mathrm{DM}$ and from 65 to $22 \mathrm{mg} \mathrm{kg}^{-1} \mathrm{DM}$, respectively, whereas significantly increased in mature and old ones for all metals (from 0.90 to $6.4,63$ to 497, 17 to $474 \mathrm{mg} \mathrm{kg}^{-1} \mathrm{DM}$ of $\mathrm{Cd}$, $\mathrm{Zn}$ and $\mathrm{Cu}$ respectively). In the achenes of the treated plants at the maturity stage (Figure 5), Cd concentration showed the lowest value $\left(0.37 \mathrm{mg} \mathrm{kg}^{-1} \mathrm{DM}\right)$, followed by $\mathrm{Cu}(18$ $\left.\mathrm{mg} \mathrm{kg}^{-1} \mathrm{DM}\right)$ and $\mathrm{Zn}\left(70 \mathrm{mg} \mathrm{kg}^{-1} \mathrm{DM}\right)$. Except for Zn, significant differ-

Table 2. Cadmium, zinc, copper concentrations in young leaves, mature and old ones respectively at the top, middle and basal portion of the plant.

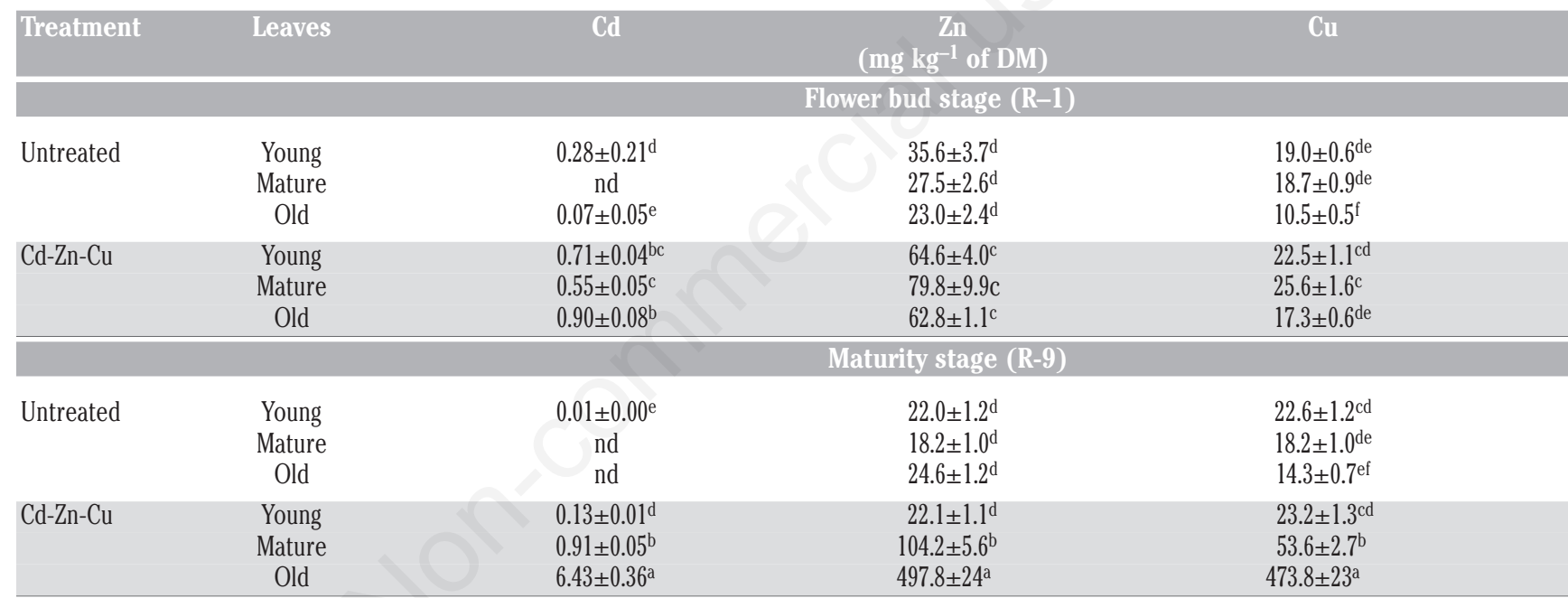

Values are means $(\mathrm{n}=4) \pm$ SE. Data were analyzed independently by ANOVA to evaluate the effect of the treatment, stage, portion and the interaction among them. The significant level of $\mathrm{F}$ ratio was $\leq 0.001$ for all factors and interactions. ${ }^{\text {a-f }}$ For each metal, values followed by the same letters are not significantly different for P $\leq 0.05$ according to Duncan's test. DM, dry matter; nd, not detected; $\mathrm{Cd}$, cadmium; Zn, zinc; $\mathrm{Cu}$, copper.

Table 3. Bioconcentration factor relative to the aerial part and old leaves in the treated plant at the flower bud (R-1) and maturity (R-9) stages.

\begin{tabular}{|c|c|c|c|c|}
\hline \multicolumn{5}{|c|}{ Bioconcentration factor (-) } \\
\hline & \multicolumn{2}{|c|}{ Aerial part } & \multicolumn{2}{|c|}{ Old leaves } \\
\hline Metal & R-1 & R-9 & R-1 & R-9 \\
\hline $\mathrm{Cd}$ & $0.11 \pm 0.01$ & $0.17 \pm 0.01$ & $0.18 \pm 0.02^{\mathrm{d}}$ & $1.43 \pm 0.07^{\mathrm{a}}$ \\
\hline Zn & $0.11 \pm 0.01$ & $0.17 \pm 0.01$ & $0.09 \pm 0.00^{\mathrm{d}}$ & $0.67 \pm 0.02^{c}$ \\
\hline $\mathrm{Cu}$ & $0.03 \pm 0.01$ & $0.09 \pm 0.01$ & $0.04 \pm 0.00^{\mathrm{d}}$ & $0.95 \pm 0.03^{b}$ \\
\hline \multicolumn{5}{|c|}{ Significance } \\
\hline Metal & \multicolumn{2}{|c|}{$* * *$} & \multicolumn{2}{|c|}{$* * *$} \\
\hline Stage & \multicolumn{2}{|c|}{$* * *$} & \multicolumn{2}{|c|}{$* * *$} \\
\hline $\mathrm{M} \times \mathrm{S}$ & \multicolumn{2}{|c|}{ ns } & \multicolumn{2}{|c|}{$* * *$} \\
\hline
\end{tabular}

Values are means $(\mathrm{n}=4) \pm \mathrm{SE}$. Data were analyzed independently by two-way ANOVA to evaluate the effect of metal $(\mathrm{M})$ and phenological stage $(\mathrm{S})$ and the interaction of this two factors $(\mathrm{M} \times \mathrm{S})$. The significance leve of the $\mathrm{F}$ ratio is reported and indicated with asterisks: ${ }^{* * *}$ for $\mathrm{P} \leq 0.001$. ${ }^{\mathrm{a}-\mathrm{d}}$ For old leaves, values followed by the same letters are not significantly different for $\mathrm{P} \leq 0.05$ according to Duncan's test. ns, not significant; $\mathrm{Cd}$, cadmium; Zn, zinc; Cu, copper. 

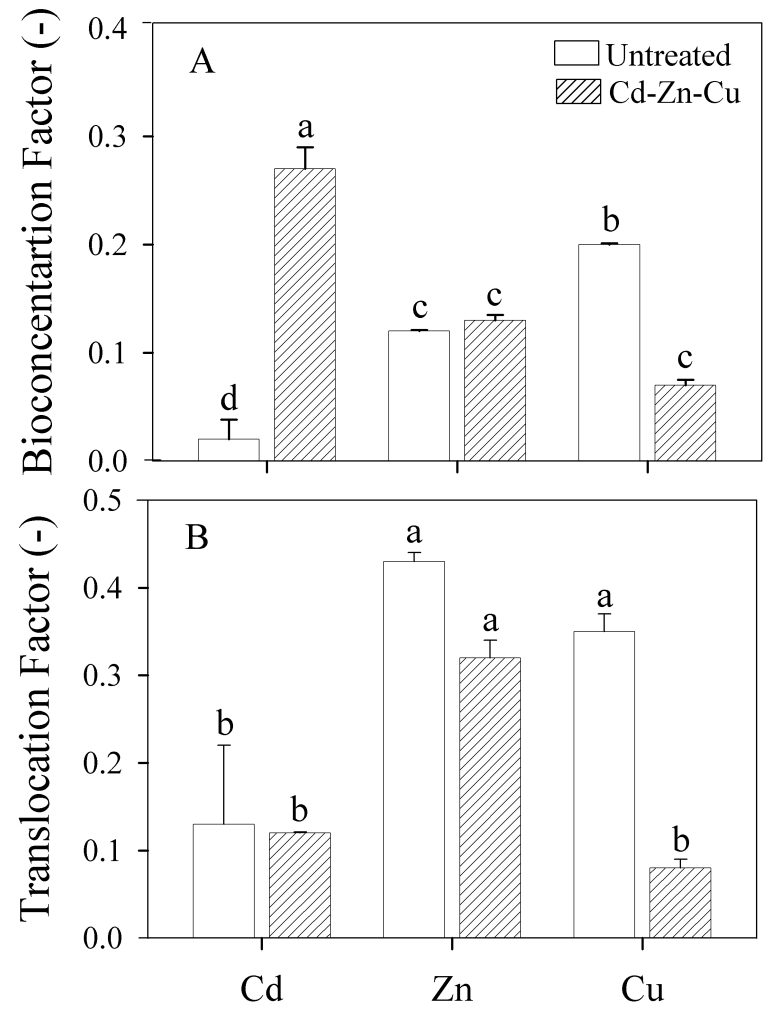

Figure 3. Bioconcentration (A) and translocation factor (B) of cadmium $(\mathrm{Cd})$, zinc $(\mathrm{Zn})$ and copper $(\mathrm{Cu})$ in sunflower plants at flower bud stage $(R-1)$. Values are means $(n=4) \pm S E$. In each graph, bars followed by the same letters are not significantly different for $\mathbf{P} \leq \mathbf{0 . 0 5}$ according to Duncan's test. ences between treatments were observed for $\mathrm{Cd}$ and $\mathrm{Cu}$.

Finally, in Table 3 has been reported BCF calculated considering the aerial part and only the old leaves for the 3 metals in both phenological stages (Table 3). For all metals BCF was significantly higher at the maturity stage (R-9) than at the flower bud stage (R-1) both in the aerial part and in the old leaves of the basal portion of the stem. The highest values of BCF were found in the old leaves at R-9 stage (1.4, 0.67 and 0.9 of $\mathrm{Cd}, \mathrm{Zn}$ and $\mathrm{Cu}$, respectively).

\section{Discussion}

Heavy metal accumulation and distribution in plants are both specieand metal-specific and seem to depend also on metal concentration and combination in the medium of growth. About sunflower, there are not univocal reports on heavy metal accumulation and distribution in plant, as they are dependent on several endogenous (e.g., genotype, phenological stages) (Li et al., 1997; Madejón et al., 2003; Nehnevajova et al., $2005)$ and exogenous (e.g., combination, concentration and bioavailability of metals in soil, culture system used) (January et al., 2008; Rivelli et al., 2012) factors. Results of this experiment showed that sunflower accumulated considerable amounts of heavy metals in both analyzed phenological stages with slight effects on growth and DM of the plant. In particular, a significant reduction was found only in the stem at the flower bud phase, the heads instead significantly increased by $10 \%$ in the R-1 stage and decreased by $37 \%$ at R-9 stage. The increasing in head dry matter during the flower bud stage could be due to a premature flower induction stimulated by heavy metals. In fact, according to many authors, heavy metal stress induces a stimulation of ethylene production hormone which regulates several physiological and growth processes in plants, particularly senescence, plant growth and
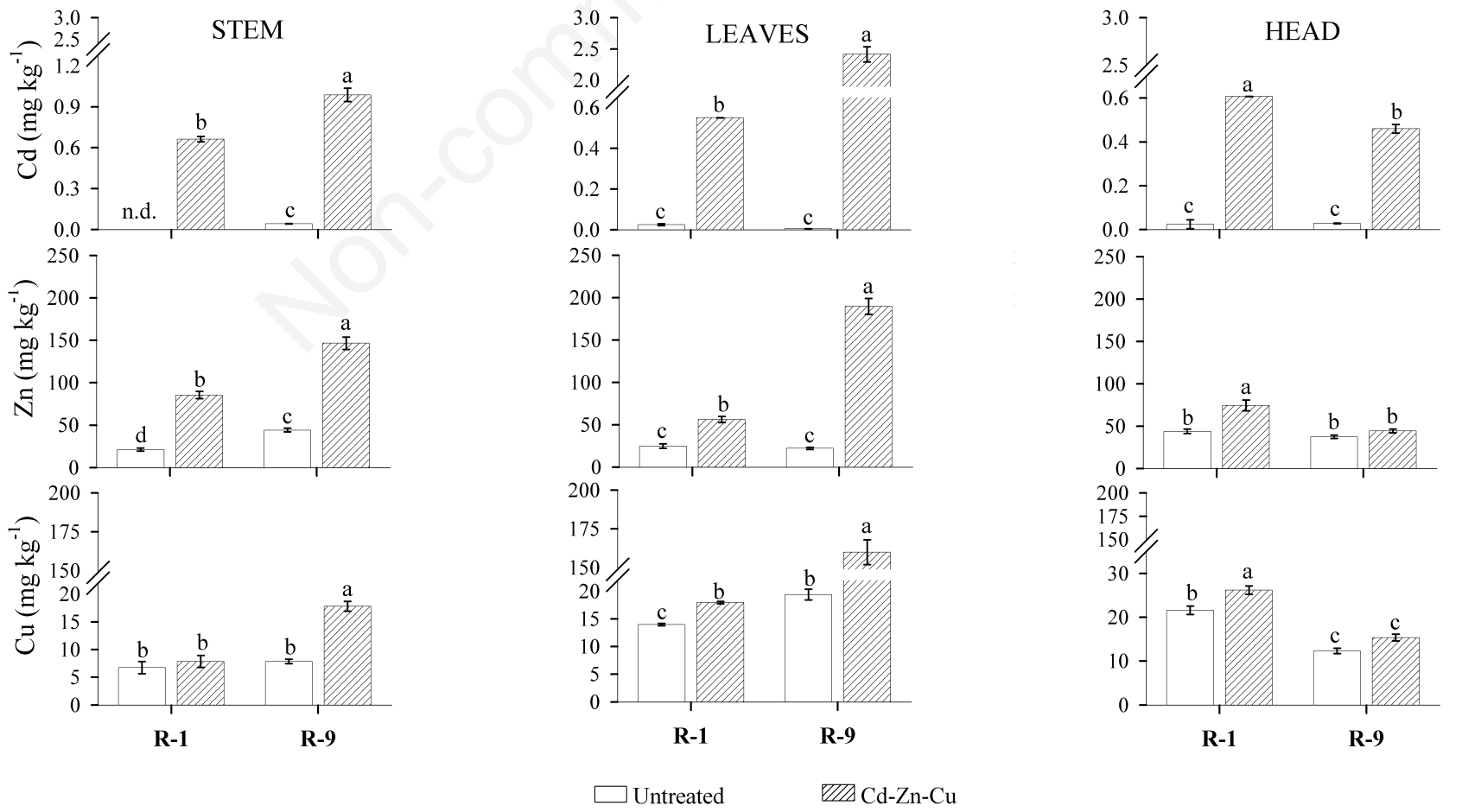

Figure 4. Cadmium $(\mathrm{Cd})$, zinc $(\mathrm{Zn})$ and copper $(\mathrm{Cu})$ concentrations in stem, leaves and head in plant of sunflower at both flower bud $(\mathrm{R}-1)$ and maturity (R-9) stages. Values are means $(n=4) \pm$ SE. For each metal in each portions of the plant, bars followed by the same letters are not significantly different for $\mathrm{P} \leq \mathbf{0 . 0 5}$ according to Duncan's test. 
development including flower induction (Abeles et al., 1992; Liu et al., 1997; Arteca and Arteca, 2007). However, in our experiment, plants grown on contaminated soil did not display further macroscopic stress symptoms. These results may be due to the fact that sunflower accumulated the metals mainly in the roots (with concentrations of $\mathrm{Cd}, \mathrm{Zn}$ and $\mathrm{Cu}$ respectively up to $5.4,233$ and $160 \mathrm{mg} \mathrm{kg}^{-1} \mathrm{DM}$ ) with a low translocation of the three metals from the roots to the aerial part in which, the concentration of $\mathrm{Cd}, \mathrm{Zn}$ and $\mathrm{Cu}$ were 9- 3- and 13- fold lower than in roots. According to numerous authors (Vogeli-Lange and Wagner, 1990; Ouzounidou et al., 1994), the accumulation of trace element mainly in roots is considered as one of the several strategies used by plants to tolerate metal stress. Once inside the root cells, metals are translocated by membrane metal transporters and metal-binding proteins to their final destination. This process involves a series of specific mechanisms that must to maintain a fine balance between having enough essential metals available for metabolic functions and at the same time avoiding toxicity and to keep nonessential metals below their toxicity thresholds (Clemens, 2001; Yureula, 2005). As a result, metals in excess are often stored where they are less toxic for cellular metabolism (Yureula, 2005) e.g. in roots and/or in oldest leaves. Furthermore, differences in BCF and TF factors were observed among contaminants at the end of vegetative stage, $\mathrm{R}-1$. Considering the two essential metals, $\mathrm{Cu}$ showed significantly lower BCF and TF values in the contaminated treatment with respect to the untreated plants while no significant differences between treatments were observed for $\mathrm{Zn}$. Such result could indicate that the plants of sunflower block and/or reduce the accumulation and translocation from the roots to the aerial part only of $\mathrm{Cu}$, probably because the level of contamination tested in this experiment is over the toxicity threshold value. $\mathrm{Cd}$, instead, as expected showed the highest value of BCF in the treated plant with a lowest translocation from the roots to the aerial part. The highest heavy metal accumulation in roots of sunflower with a low translocation from roots to the aerial part and the low BCF values are in accordance with the results found on this specie by several authors (Lin et al., 2003; Soudek et al., 2010; Chaves et al., 2011). Furthermore, Vamerali et al. (2012) in a recent paper, in which summarized the main results of 10 years of study conducted on plants grown on metal-polluted soils, highlighted the key role of plant roots in plant-based remediation technologies, such as phytoextraction and phytostabilization, since more roots are expected to take up a greater amount of pollutants, and they represent a significant metal

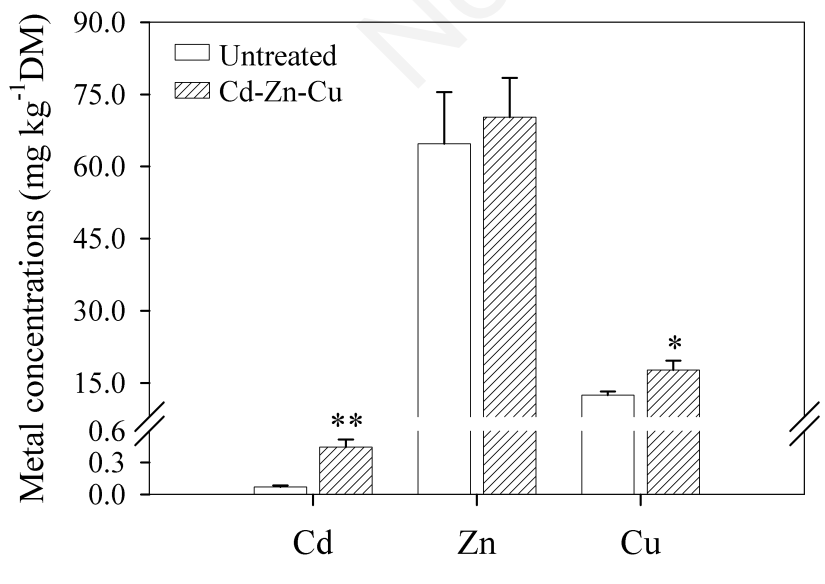

Figure 5. Cadmium $(\mathrm{Cd})$, zinc $(\mathrm{Zn})$ and copper $(\mathrm{Cu})$ concentrations in the achenes at the maturity stage. Values are means $(n=4) \pm S E$. Significant differences from the control are labelled with asterisk $\left({ }^{*}\right):{ }^{*} \mathbf{P} \leq 0.05 ;{ }^{* *} \mathbf{P} \leq 0.01$ according to Student's Test. DM, dry matter. sink. In this context, sunflower, as highlighted by several authors, seems to be a promising candidate in the phytoremediation technologies (e.g. phytostabilization, rhizodegradation) (Madejòn et al., 2003; Meers et al., 2005; Prasad, 2007; Soudek et al., 2010).

Considering only the above-ground biomass differences in the accumulation and distribution of contaminants were found among the three metals passing from R-1 to R-9 stage. The accumulation of the trace elements increased in leaves and stem and decreased in head passing from flower bud stage to the physiological maturity, showing similar distribution pattern for $\mathrm{Cd}$ and $\mathrm{Zn}$. Passing from flowering to the harvesting time, similar results in metals accumulation $(\mathrm{Cd}, \mathrm{Zn}, \mathrm{Cu}$ and $\mathrm{Pb}$ ) has been reported by Herrero et al. (2003) in sunflower and oil seed rape. At maturity stage, the largest accumulation of $\mathrm{Cd}, \mathrm{Zn}$ and $\mathrm{Cu}$ in plant was found in the leaves, mainly in the old ones, followed by stem and head. In literature, similarities in the accumulation pattern of $\mathrm{Cd}$ and $\mathrm{Zn}$ were often reported for sunflower as well as for other species (Küpper et al., 2000; Ma et al., 2005; Chaves et al., 2011; De Maria et al., 2011). The increase of metals concentration in old leaves and their decrease in young leaves and head, passing from R-1 to R-9, as highlighted also comparing the BCF calculated in relation to old leaves to those calculated in relation to the aerial part, could be interpreted as a probable re-translocation of the three metals along the plant with the aim to preserve photosynthesizing tissues and reproductive organs from toxic levels. Restriction of toxic ions transport towards young leaves and storage in old leaves has been observed on the same specie/genotype also for $\mathrm{Cl}$ ions stress in salinity condition (Rivelli $e t$ al., 2010). Such strategy appears to be involved primarily in avoiding the accumulation of toxic concentrations at sensitive sites within the cell preventing the damaging effects rather than developing proteins that can resist the heavy metal effects (Yureula, 2005). The potential cellular mechanisms involved in tolerance include chelation with phytochelatins, metallothioneins, vacuolar compartmentalization and sequestration, induction of mechanisms to compensate the effects of reactive oxygen species such as the biosynthesis of antioxidant molecules and stress proteins, and upregulation of peroxidase synthesis (Salt et al., 1995; Yureula, 2005). As a result of the redistribution of metals in plant, the concentrations of $\mathrm{Cd}, \mathrm{Zn}$ and $\mathrm{Cu}$ in the seeds were very low and not exceeded the toxicity threshold values considered for livestock (Chaney, 1989; European Commission, 2002.). As suggested by Madejòn et al. (2003) sunflower can be considered for plant-based remediation technologies for many reason, including the low risk for the food web since its tough leaves and the stem are rarely eaten by animals and the seeds (which conversely are actively eaten by birds) have very low concentrations of potentially toxic elements.

Overall, the preliminary results obtained in this experiment are in agreement with those reported by several other authors, which indicate the sunflower as a specie potentially suitable for phytoremediation strategies (Lin et al., 2003; Madejòn et al., 2003; Marchiol et al., 2007; Prasad, 2007; Sodek et al., 2010). Nevertheless for this specie, as well as for many others forestry and agricultural crops, there is still much fundamental, applied and field research needed. Indeed, although are known several traits of the species candidate for phytotecnologies such as high efficiency in removing heavy metals and tolerance to contaminants, fast-growing and appreciable biomass production, ease of agronomic management and low demand of auxiliary energy during cultivation, and economic interest for the harvestable biomass (Lasat 2000; Meers et al., 2005; Tognetti et al., 2013) - they are still not fully understood.

However, our data on accumulation and distribution of trace elements in plant, though they are to be tested in open field, still provide useful information to address further studies to focus on the agronomic practices that would optimize the phytoremediation processes to site-specific conditions and the real capacity of sunflower to remove 
contaminants from contaminated environments. Indeed, based on responses to heavy metals in controlled condition, many species, including sunflower, appear promising for phytoremediation, but their real potential has not been fully clarified due to the scarcity of field trials. In addition as recently indicated in a review by Dickinson $e t$ al. (2009), it is important to treat sceptically any data obtained from hydroponics, pot experiments, or spiked soils on the grounds that there is a high probability these methods will not accurately reflect concentrations in field-grown plants.

\section{Conclusions}

Sunflower seems to be tolerant to heavy metal stress applied by accumulating in the harvestable biomass considerable amount of contaminants (up to 0.04, 5.4 and $2.1 \mathrm{mg}$ per plant $\mathrm{DM}$ of $\mathrm{Cd}, \mathrm{Zn}$ and $\mathrm{Cu}$, respectively) without significative effects on plant growth. Metals were accumulated mainly in roots and old leaves with a low translocation from roots to the aerial part. Differences in accumulation and distribution of the three metals were found between the two phenological stages and among the different portions/organs of the plants. The high storage of heavy metals in roots and old leaves and the re-translocation of the three metals along the plant during the growing cycle could be considered as a strategy of sunflower to preserve young metabolically-active leaves and reproductive organs from toxic metal concentrations.

The appreciable DM production and the considerable accumulation of trace elements in the tissues make sunflower interesting for plantbased remediation technologies. Such specie is an increasingly important source of vegetable oil and biomass, usefully employed for chemical, energy and industrial purposes (Riva and Calzoni, 2004) and its importance as environmental crop for phytotechnologies to clean-up inorganic and organic contaminants and pollutants is being increasingly recognized (Meers et al., 2005; Prasad, 2007; Adesodun et al., 2010). It is the most promising terrestrial candidate for metal and radionuclides removal from water by rhizofiltration (Prasad and Freitas, 2003). Furthermore, as reported in update reviews (Dickinson et al., 2009; Tognetti et al., 2013), it is now generally agreed that biomass crops have a small but significant role to play in both local and global energy policies in the future. Accordingly, many studies are currently oriented to combining phytoremediation with crops of commercial interest, with the aim of achieving gradually soil decontamination at low cost by producing commercial resources, such as timber or bioenergy, usable for technical purposes and generating value added. Marginal land not used for agriculture, forestry, or urban development has the greatest potential for yielding biomass energy, and it is likely that energy crops, including sunflower, are compatible with providing other environmental services including both the management of soil contaminants and waste recycling.

\section{References}

Abeles FB, Morgan PW, Saltveit jr. ME, 1992. Ethylene in plant biology, 2nd ed. Academic Press, San Diego, CA, USA.

Adesodun JK, Atayese MO, Agbaje TA, Osadiaye BA, Mafe OF, Soretire AA, 2010. Phytoremediation potentials of sunflowers (Tithonia diversifolia and Helianthus annuus) for metals in soils contaminated with zinc and lead nitrates. Water Air Soil Pollut. 207:195-201.

Arteca RN, Arteca JM, 2007. Heavy-metal-induced ethylene production in Arabidopsis thaliana. J. Plant Physiol. 164:1480-8.
Baker AJM, McGrath SP, Reeves RD, Smith JAC, 2000. Metal hyperaccumulator plants: a review of the ecology and physiology of a biochemical resource for phytoremediation of metal-polluted soil. In: N. Terry and G. Banuelos (eds.) Phytoremediation of contaminated soil and water. CRC Press Inc., Lewis Boca Raton, FL, USA, pp 85-107.

Chaney RL, 1983. Plant uptake of inorganic waste constitutes. In: J.E. Parr, P.B. Marsh and J.M. Kla (eds.) Land treatment of hazardous wastes. Noyes Data Corporation, Park Ridge, NJ, USA, pp 50-76.

Chaney RL, 1989. Toxic element accumulation in soil and crops: protecting soil fertility and agricultural food-chains. In: B. Bar-Yosef, N.J. Barrow and J. Goldshmid (eds). Inorganic contaminants in the Vadose Zone. Springer-Verlag, Berlin, Germany, pp 140-158.

Chaves LHG, Estrela MA, de Souza RS, 2011. Effect on plant growth and heavy metal accumulation by sunflower. J. Phytology 3:4-9.

Clemens S, 2001. Molecular mechanisms of plant metal tolerance and homeostasis. Planta 212:475-86.

Cunningham SD, Ow DW, 1996. Promises and prospects of phytoremediation. Plant Physiol. 110:715-9.

De Maria S, Rivelli AR, Kuffner M, Sessitsch A, Wenzel WW, Gorfer M, Strauss J, Puschenreiter M, 2011. Interactions between accumulation of trace elements and major nutrients in Salix caprea after inoculation with rhizosphere microorganisms. Chemosphere $84: 1256-61$.

Dickinson NM, Baker AJM, Doronila A, Laidlaw S, Reeves RD, 2009. Phytoremediation of inorganics: realism and synergies. Int. J. Phytoremediat. 11:97-114.

EEA, 2007. Progress in management of contaminated sites. Reports CSI 015. EEA Publ. Available from: http://www.eea.europa.eu/data-andmaps/indicators/progress-in-management-of-contaminatedsites/progress-in-management-of-contaminated-1

European Commission, 2002. Directive 2002/32/EC of the European Parliament and of the Council of 7 May 2002 on undesirable substances in animal feed. In: Official Journal, L 140, 30/05/2002, pp 10-21.

Garbisu C, Alkorta I, 2001. Phytoextraction: a cost effective plant based technology for the removal of metals from the environment. Bioresource Technol. 77:229-36.

Garbisu C, Hernandez-Allica J, Barrutia 0, Alkorta I, Becerril JM, 2002. Phytoremediation: a technology using green plants to remove contaminants from polluted areas. Rev. Environ. Health 17:173-88.

Ghosh M, Singh SP, 2005. A review on phytoremediation of heavy metals and utilization of its byproducts. Ap. Ecol. Environ. Res. 3:1-18.

Herrero EM, López-Gonzálvez A, Ruiz MA, Lucas-García JA, Barbas C, 2003. Uptake and Distribution of Zinc, Cadmium, Lead and Copper in Brassica napus var. oleífera and Helianthus annus Grown in Contaminated Soils. Int. J. Phytoremediat. 5:153-67.

January MC, Cutright TJ, Van Keulen H, Wei R, 2008. Hydroponic phytoremediation of $\mathrm{Cd}, \mathrm{Cr}, \mathrm{Ni}, \mathrm{As}$, and Fe: can Helianthus annuus hyperaccumulate multiple heavy metals? Chemosphere 70:531-7.

Küpper H, Lombi E, Zhao FJ, McGrath SP, 2000. Cellular compartmentation of cadmium and zinc in relation to other elements in the hyperaccumulator Arabidopsis halleri. Planta 212:75-84.

Lasat MM, 2000. Phytoextraction of metals from contaminated soil: a review of plant/soil/metal interaction and assessment of pertinent agronomic issues. J. Hazard. Subst. Res. 3:1-25.

Leita L, Petruzzelli G, 2000. Metalli pesanti. In: P. Sequi and P. Violante (eds.) Metodi di analisi chimica del suolo. Cap. XI. Collana di metodi analitici per l'agricoltura. Franco Angeli Ed., Milano, Italy, pp 118.

Li YM, Chaney RL, Schneiter AA, Miller JF, Elias EM, Hammond JJ, 2005. Screening for low grain cadmium phenotypes in sunflower, durum wheat and flax. Euphytica 94:23-30. 
Lin J, Jiang W, Liu D, 2003. Accumulation of copper by roots, hypocotyls, cotyledons and leaves of sunflower (Helianthus annuus L.). Bioresource Technol. 86:151-5.

Liu JH, Lee-Tamon SH, Reid DM, 1997. Differential and woundinducible expression of 1-aminocyclopropane-1-carboxylate oxidase genes in sunflower seedlings. Plant Mol. Biol. 34:923-33.

Ma JF, Ueno D, Zhao FJ, McGrath SP, 2005. Subcellular localisation of $\mathrm{Cd}$ and $\mathrm{Zn}$ in the leaves of a Cd-hyperaccumulating ecotype of Thlaspi caerulescens. Planta 220:731-6.

Madejón P, Murillo JM, Marañón T, Cabrera F, Soriano MA, 2003. Trace element and nutrient accumulation in sunflower plants two years after the Aznalcóllar mine spill. Sci. Tot. Environ. 307:239-57.

Marchiol L, Fellet G, 2011. Agronomy towards the Green Economy. Optimization of metal phytoextraction. Ital. J. Agr. 6:e30.

Marchiol L, Fellet G, Perosa D, Zerbi G, 2007. Removal of trace metals by Sorghum bicolor and Helianthus annuus in a site polluted by industrial wastes: a field experience. Plant Phisiol. Biochem. 45:379-87.

Marques A, Rangel A, Castro P, 2009. Remediation of heavy metal contaminated soils: phytoremediation as a potentially promising clean-up technology. Crit. Rev. Environ. Sci. Technol. 39:622-54.

Meers E, Ruttens A, Hopgood M, Lesage E, Tack FMG, 2005. Potential of Brassic rapa, Cannabis sativa, Helianthus annuus and Zea mays for phytoextraction of heavy metals from calcareous dredged sediment derived soils. Chemosphere 61:561-72.

Nehnevajova E, Herzig R, Federer G, Erismann KH, Schwitzguébel JP, 2005. Screening of sunflower cultivars for metal phytoextraction in a contaminated field prior to mutagenesis. Int. J. Phytoremediat. 7:337-49.

Ouzounidou G, Symeonidis L, Babalonas D, Karataglis S, 1994. Comparative responses of a copper-tolerant and a copper-sensitive population of Minuartia hirsuta to copper toxicity. J. Plant Physiol. 144:109-15.

Prasad MNV, 2007. Sunflower (Helianthus annuus L.) - a potential crop for environmental industry. Helia 30:167-74.

Prasad MNV, Freitas HMO, 2003. Metal hyperaccumulation in plants biodiversity prospecting for phytoremediation technology. Nat. Biotechnol. 6:1-27.

Riva G, Calzoni J, 2004. Standardisation of vegetable oils. Riv. Agron. 1:9-15.

Rivelli AR, De Maria S, Pizza S, Gherbin P, 2010. Growth and physiological response of hydroponically-grown sunflower as affected by salinity and magnesium levels. J. Plant. Nutr. 33:1307-23.

Rivelli AR, De Maria S, Puschenreiter M, Gherbin P, 2012. Accumulation of Cadmium, Zinc and Copper by Helianthus annuus L.: impact on plant growth and uptake of nutritional elements. Int. J. Phytoremediat. 14:320-34.

Salt DE, Prince RC, Pickering IJ, Raskin I, 1995. Mechanisms of cadmium mobility and accumulation in Indian mustard. Plant Physiol. 109:1427-33.

Schneiter, AA, Miller JF, 1981. Description of sunflower growth stages. Crop Sci. 21:901-3.

Singh R, Gautam N, Mishra A, Gupta R, 2011. Heavy metals and living systems: an overview. Indian J. Pharmacol. 43:246-53.

Soudek P, Petrova S, Benesova D, Vanek T, 2010. Phytoextraction of toxic metals by sunflower and corn plants. Int. J. Food Agric. Environ. 8:383-90.

Tognetti R, Cocozza C, Marchetti M, 2013. Shaping the multifunctional tree: the use of Salicaceae in environmental restoration. iForest Biogeosci. For. 6:37.

Vamerali T, Marchiol L, Bandiera M, Fellet G, Dickinson NM, Lucchini P, Mosca G, Zerbi G, 2012. Advances in agronomic management of phytoremediation: methods and results from a 10-year study of metal-polluted soils. Ital. J. Agr. 7:e42.

Vogeli-Lange R, Wagner GJ, 1990. Subcellular localization of cadmium and cadmium-binding peptides in tobacco leaves. Plant Physiol. 92:1086-93.

Yureula I, 2005. Copper in plants. Braz. J. Plant Phisiol. 17:145-56. 